Annals of Plant and Soil Research 23(2): 215-217 (2021)

https://doi.org/10.47815/apsr.2021.10060

\title{
Genetic variability, Heritability and Genetic advance studies in Yardlong bean (Vigna unguiculata spp. sesquipedalis) genotypes
}

\author{
K. RAMKUMAR AND S. ANUJA \\ Department of Horticulture, Faculty of Agriculture, Annamalai University, Annamalainagar, Tamilnadu, \\ India. 608002
}

Received: March, 2021; Revised accepted: April, 2021

\begin{abstract}
A field experiment was carried out at farmer field in Pudukurapettai village, Virudhachalam, Tamilnadu during 2019 to study genetic variability, heritability and genetic advance expressed as per cent of mean for yield and yield attributing characters in thirty three genotypes of yardlong bean. The mean performance recorded on days to first flowering was in the range of (46.78 to 57.33 days), vine length (196.76 to $386.32 \mathrm{~cm}$ ), days to first picking (57.33 to 67.53 days), pod length $(14.18$ to $60.08 \mathrm{~cm})$, pod width $(1.76$ to $3.43 \mathrm{~cm})$, fresh pod weight (171.43 to $995.45 \mathrm{~g}$ ), number of pods per plant (26.53 to 56.40), number of picking (10.00 to 14.20) and pod yield per plant (171.43 to $995.45 \mathrm{~g}$ ). The genotypic and phenotypic coefficient of variation showed higher value for pod yield per plant (46.69 \% and $46.70 \%$ ), fresh pod weight (42.27 and $42.28 \%$ ) and pod length (41.66 and $41.66 \%)$. High heritability was observed for the all nine characters. Genetic advance as per cent of mean was higher for pod yield per plant (96.18\%), fresh pod weight (87.08\%), pod length (85.81\%), vine length (36.93 $\%)$, pod width (34.16\%) and number of pods per plant (30.04\%).
\end{abstract}

Keywords: Yardlong bean, Range, GCV, PCV, heritability and genetic advance

\section{INTRODUCTION}

Yardlong bean Vigna unguiculata spp. sesquipedalis belonging to family Leguminaceae is cultivated mainly for its crisp and tender green pods which are consumed in both fresh as well as in cooked form. It is also known as Snake bean, Asparagus bean due to its long slender pods. Yard long bean is considered to be originated in Central Africa and widely distributed in India, Indonesia, Phillippines and Sri-Lanka. Estimating the parameters of variability, especially heritability and genetic gain are important indicators for improvement of characters through selection whereas the selection for highly heritable characters is more effective. Therefore, heritability along with other parameters of variability can be used in predicting the gain for a given selection intensity and expected genetic gain further gives the idea of the extent of improvement in a character through simple selection (Yumkhaibam et al, 2019). The objective of this study was to analyse the genetic variability, heritability and genetic advance studies of yardlong bean for better crop improvement.

\section{MATERIALS AND METHODS}

The present investigation was carried at farmer's field in Pudukurapettai village, Virudhachalam, Tamilnadu during the January 2019 to April 2019. Thirty three genotypes viz. IC- 622569, IC- 622579, IC-622590, IC -622597, IC- 622598, IC- 622599, IC-622600, IC -622601, IC- 622602, IC- 626137, IC- 626138, IC-626139, IC-626140, IC- 626142, IC -626143, IC-626145, IC-626146, IC-626147, IC-626148, IC-626149, IC-626152, IC 630380, IC 630381, IC-626153, IC-626154, IC-630377, IC-630378, IC-630379, IC-630383 were evaluated in randomized block design with three replications with spacing of $1.50 \times 0.45 \mathrm{~m}$. The size of the each experimental plot is $8.75 \mathrm{~m}$. The seeds were directly sown in experimental field on $5^{\text {th }}$ January 2019. Manures and fertilizers were applied as per recommended dose viz. 25 tonnes of farmyard manure ha ${ }^{-1}$ and recommended dose of fertilizer 25:75:60 kg NPK $\mathrm{ha}^{-1}$. Observations were recorded on randomly selected five plants in each experimental plot. The observations were recorded on days to first flowering, vine length $(\mathrm{cm})$, days to first picking, pod length $(\mathrm{cm})$, pod width $(\mathrm{cm})$, fresh pod weight $(\mathrm{g})$, number of pods per plant, number of pickings and pod yield per plant (g). The 
variability for different quantitative characters was estimated as per the procedure for analysis of variance suggested by Panse and Sukhatme (1978), genotypic and phenotypic coefficient of variation were worked out by the formulae given by Burton (1952). According to Sivasubramanian and Madhavamenon, (1973), the phenotypic and genotypic co-efficient of variation were classified into three categories (Low=below $10 \%$, Moderate- 10-20 \% and High=above $20 \%$ ). Heritability in broad sense was calculated according to Lush (1940) expressed in percentage, Sivasubramanian and Madhavamenon, (1973) classified heritability estimate of cultivated plants into three categories $($ Low $=30 \%$, Moderate $=30-60 \%$ and High $=$ above $60 \%$ ). Genetic advance was worked out based on the formula given by Johnson et al. (1955). According to Robinson et al. (1949), genetic advance as per cent of mean was classified into three categories (Low $=$ below 10 $\%$, Moderate $=10-20 \%$ and High $=$ above 20 $\%)$.

\section{RESULTS AND DISCUSSION}

The analysis of variance on days to first flowering, vine length $(\mathrm{cm})$, days to first picking, pod length $(\mathrm{cm})$, pod width $(\mathrm{cm})$, fresh pod weight $(\mathrm{g})$, number of pods per plant, number of picking and pod yield per plant $(\mathrm{g})$ showed significant variation for the traits among the different accessions (Table 1). The analysis of variance showed significant differences among the thirty three genotypes for all the nine characters indicating the existence of genetic variability. The results obtained were in the confirmation with those of Magalingam et al, (2013) in dolichos bean; Siddika et al, (2013) in garden pea and Kumar et al, (2014) in cluster bean. The ranges in days to first flowering (46.78 to 57.33 days), vine length (196.76 to $386.32 \mathrm{~cm}$ ), days to first picking (57.33 to 67.53 days), pod length (14.18 to $60.08 \mathrm{~cm})$, pod width $(1.76$ to $3.43 \mathrm{~cm})$, fresh pod weight $(5.42$ to $27.27 \mathrm{~g}$ ), number of pods per plant $(26.53$ to 56.40 ), number of pickings ( 10.00 to 14.20 ) and pod yield per plant (171.43 to $995.45 \mathrm{~g}$ ) were recorded in yardling bean genotypes.

Variability was measured by estimation of mean, coefficient of variation such as genotypic coefficient of variation, phenotypic coefficient of variation, heritability and genetic advance (Table 2). The results indicated that phenotypic coefficient of variation was higher than the genotypic coefficient of variation for all the characters indicating the influence of the environments to some degree. Similar observations were reported by Parmar et al, (2013) in dolichos bean and Prakash et al, (2015) in french bean. The genotypic coefficient of variation showed a range of 3.29 to $46.69 \%$. Highest GCV was recorded for pod yield per plant $(46.69 \%)$, fresh pod weight $(42.27 \%)$ and pod length (41.66 \%). whereas it was moderate for vine length $(17.93 \%)$ and pod width $(16.69 \%)$ and number of pods per plant (14.61 $\%)$. The lowest GCV was recorded for number of picking $(9.29 \%)$, days to first flowering (5.06 \%) and days to first picking (3.29\%).

Table 1: Analysis of variance for morphological characters of Yardlong bean

\begin{tabular}{|c|c|c|c|c|}
\hline \multirow{3}{*}{ S. No. } & \multirow{3}{*}{ Characters } & \multicolumn{3}{|c|}{ Mean Sum of Square } \\
\hline & & Replication & Genotype & Error \\
\hline & & $d f=2$ & $d f=32$ & $\mathrm{df}=64$ \\
\hline 1. & Days to $1^{\text {st }}$ flowering & 0.761 & $21.405^{\star \star}$ & 0.123 \\
\hline 2. & Vine length $\mathrm{cm}$ ) & 0.170 & $8325.190^{\star \star}$ & 2.760 \\
\hline 3. & Days to $1^{\text {st }}$ picking & 0.508 & $13.673^{* *}$ & 0.223 \\
\hline 4. & Pod length $(\mathrm{cm})$ & 0.165 & $439.939^{* *}$ & 0.007 \\
\hline 5. & Pod width (cm) & 0.006 & $0.529^{\star \star}$ & 0.002 \\
\hline 6. & Fresh pod weight & 0.0003 & $77.669^{\star *}$ & 0.007 \\
\hline 7. & Pods / plant & 0.320 & $86.627^{\star \star}$ & 0.137 \\
\hline 8. & Number of picking & 0.932 & $3.597^{\star \star}$ & 0.035 \\
\hline 9. & Pod yield / plant & 9.764 & $129155.128^{\star \star}$ & 9.369 \\
\hline
\end{tabular}

*Significant at 5\%, ${ }^{\star *}$ Significant at 1\%

The phenotypic coefficient of variation showed a range of 3.37 to $46.70 \%$. Highest PCV was recorded for pod yield per plant (46.70
$\%)$, fresh pod weight (42.28 \%) and pod length $(41.66 \%)$. whereas it was moderate for vine length $(17.94 \%)$, pod width $(16.81 \%)$ and 
number of pod per plant (14.65\%). The magnitude of PCV was, in general, higher than corresponding GCV indicating the influence of environmental factors in their expression (Johnson et al, 1955). These results are similar to those of Magalingam et al, (2013) and Singh et al, (2016), which indicated that greater the genetic variability among the parents, more are the chances of further improvement. This shows more preponderance of environmental factors of yield and yield attributing characters in yardlong bean. The lowest GCV was recorded for number of picking (9.42 \%), days to first flowering (5.11 $\%)$ and days to first picking (3.37\%). In the present study, pod yield per plant, fresh pod weight and pod length recorded high PCV and GCV which coincides with the results obtained by Magalingam et al, (2013) in dolichos bean. Kumar et al, (2014) in cluster bean and Singh et al, (2016) in winged bean. Moderate GCV and PCV were reported by Goudar et al, (2017) in cluster bean, Siddika et al, (2013) in pea and Dewangan et al, (2017) in dolichos bean. Lower GCV and PCV was recorded for days to first flowering, days to first picking and number of picking. The results are in consonance with the results of Singh et al, (2016) and Ghimire et al, (2019) in common bean.

Table 2: Comparison of magnitude of variability, heritability and genetic advance as per cent of mean for different morphological traits in Yardlong bean

\begin{tabular}{|l|c|c|c|c|c|c|c|}
\hline \multirow{2}{*}{\multicolumn{1}{c}{ Characters }} & General & \multicolumn{2}{c|}{ Range } & \multirow{2}{*}{ GCV \% } & \multirow{2}{*}{ PCV \% } & $\mathrm{H}^{2} \%$ & \multirow{2}{*}{ GAM \% } \\
\cline { 3 - 6 } & Mean & Minimum & Maximum & & & \\
\hline Days to 1 $1^{\text {st }}$ flowering & 52.54 & 46.78 & 57.33 & 5.06 & 5.11 & 98.27 & 10.34 \\
Vine length cm) & 293.64 & 196.76 & 386.32 & 17.93 & 17.94 & 99.90 & 36.93 \\
Days to 1 $1^{\text {st }}$ picking & 64.26 & 57.33 & 67.53 & 3.29 & 3.37 & 95.23 & 6.62 \\
Pod length (cm) & 29.06 & 14.18 & 60.08 & 41.66 & 41.66 & 99.99 & 85.81 \\
Pod width (cm) & 2.51 & 1.76 & 3.43 & 16.69 & 16.81 & 98.64 & 34.16 \\
Fresh pod weight & 12.03 & 5.42 & 27.27 & 42.27 & 42.28 & 99.97 & 87.08 \\
Pods / plant & 36.72 & 26.53 & 56.40 & 14.61 & 14.65 & 99.52 & 30.04 \\
Number of picking & 11.72 & 10.00 & 14.20 & 9.29 & 9.42 & 97.12 & 18.86 \\
Pod yield / plant & 444.3 & 171.43 & 995.45 & 46.69 & 46.70 & 99.98 & 96.18 \\
\hline
\end{tabular}

GCV: Genotypic co-efficient of variation, PCV: Phenotypic co-efficient of variation, $\mathrm{H}^{2}$ : Heritability, GAM: Genetic advance as $\%$ of mean

The heritability is a measure of the extent of phenotypic variations caused by the action of the genes. High heritability values of all the nine characters ranged from (95.23 to 99.99 $\%)$. High heritability was observed for pod length $(99.99 \%)$, pod yield per plant $(99.98 \%)$, fresh pod weight $(99.97 \%)$, vine length $(90.90 \%)$, number of pods per plant $(99.52 \%)$, pod width $(98.64 \%)$, days to first flowering $(98.27 \%)$, number of picking $(97.12 \%)$ and days to first picking $(95.23 \%)$. Similar finding was reported by Dewangan et al, (2017) in dolichos bean. Genetic advance as per cent of mean in this study was in the range of (6.62 to $96.18 \%$ ). High genetic advance as per cent of mean were observed for pod yield per plant $(96.18 \%)$, fresh pod weight $(87.08 \%)$, pod length $(85.81 \%)$, vine length $(36.93 \%)$, pod width $(34.16 \%)$, number of pod per plant $(30.04 \%)$, indicating the least influence of environment in their expression, thus, suggesting that selection for these characters based on phenotypic appearance would be reliable. High genetic advance coupled with high heritability was observed for pod yield per plant, fresh pod weight, pod length, vine length, pod width and number of pod per plant. These results are similar to those of Dewangan et al, (2017) and Parmar et al, (2013) in dolichos bean. High heritability coupled with moderate genetic advance was observed for number of picking and days to first flowering. High heritability coupled with low genetic advance was observed for days to first picking. This indicates the influence of non additive gene action and considerable influence of environment on the expression of this trait. The results are in consonance with the results of Ukkund et al, (2007).

Based on the results of the present study, variability, heritability and genetic advance were observed higher in pod length, fresh pod weight and pod yield per plant, Hence yield improvement in yardlong bean would be achieved through the selection associated with these characters. 


\section{REFERENCES}

Burton, G.W. (1952) Quantitative inheritance in grasses. In: $6^{\text {th }}$ International Grassland Congress 1:277-283.

Dewangan, R., Bahadur, V., Choyal, P., Ramesh, Xaxa, S., Singh, V.P., Sachan, S. and Kerketta, A. (2017) Study on Genetic Variability, Heritability and Genetic Advance in Dolichos Bean (Lablab purpureus L.) Genotypes. International Journal of Current Microbiology Applied Science 6(8): 32283232.

Ghimire, N.H. and Mandal, H.N. (2019) Genetic variability, heritability and genetic advance of common bean (Phaseolus vulgaris L.) genotypes at mountain environment of Nepal. International Journal Advanced Research Biological Sciences 6(10):46-56.

Goudar, R., Srinivasa, V. and Lakshmana, D. (2017) Genetic variability and divergence studies in cluster bean [Cyamopsis tetragonoloba (L.) Taub] under hill zone of Karnataka, India. Legume Research 40(2):237-240.

Johnson, H. W., Robinson, H.F. and Comstock, R.E. (1955) Genotypic and phenotypic correlation in cluster bean and their implication in selection Agronomy Journal 47: 314-318.

Kumar, V., Ram, R.B. and Yadav, R.K. (2014) Genetic diversity in cluster bean [Cyamopsis tetragonoloba (L.) Taub.] for morphological characters. Indian Journal of Science and Technology 7(8): 11441148.

Lush, J.L. (1940) Inter-size correlation regression of offspring on dairy as a method of estimating heritability of characters. In: Amercian Society of Animal Production 33:293-301.

Magalingam, V., Yassin, M. and Kumar, S.R. (2013) Genetic variability and character association in dolichos bean. SAARC Journal of Agriculture 11(2): 161-171.

Panse, V.G. and Sukhatme, P.V. (1978) Statistical methods for agriculture, ICAR, New Delhi. pp.381.
Parmar, A.M., Singh, A.P., Dhillon, N.P.S. and Jamwal, M. (2013) Genetic variability studies for morphological and yield traits in dolichos bean (Lablab purpureus L.). World Journal of Agricultural Sciences 9(1): 24-28.

Prakash, J., Ram, R.B. and Meena, M.L. (2015) Genetic variation and characters interrelationship studies for quantitative and qualitative traits in french bean (Phaseolus vulgaris L.) under Lucknow conditions. Legume Research 38(4):425433.

Robinson, H.F., Comstock, R.F. and Harvey, P.H. (1949) Estimates of heritability and degree of dominance in corn. Agronomy Journal 41:353-359.

Siddika, A., Islam, A.K.M.A., Rasul, M.G., Mian, M.A.K. and Ahmed, J.U. (2013) Genetic variability in advanced generations of vegetable pea (Pisum sativum L.). International Journal of Plant Breeding 7(2): 124-128.

Singh, A.K., Pandey, A.K. and Nandan, R. (2016) Genetic variability and character association analysis in winged bean [Psophocorpus tetragonolobus (L.) DC.] at green pod stage. The Bioscan 11(2):1111-1115.

Sivasubramanian, S. and Madhavamenon, P. (1973) Combing ability in rice. Madras Agricultural Journal 60: 419-421.

Ukkund, K.C., Madalageri, M.B., Patil, M.P., Mulage, R. and Kotlkal, V.K. (2007) Variability studies in green chilli (Capsicum annuum L.). Karnataka Journal of Agricultural Science 20: 102104.

Yumkhaibam, T., Deo, C., Ramjan, M., Chanu, N.B. and Semba, S. (2019) Estimation of genetic variability, heritability and genetic advance for yield and its component traits of garden pea (Pisum sativum L.) in north east India. Journal of Pharmacognosy and Phytochemistry 8(3): 4034-4039. 